\title{
Mantle melting in equilibrium with an Iron-Wüstite-Graphite buffered COH-fluid
}

\author{
Sigurdur Jakobsson · John R. Holloway
}

Published online: 30 September 2008

(C) Springer-Verlag 2008

Erratum to: Contrib Mineral Petrol (2008) 155:247-256 DOI 10.1007/s00410-007-0240-6

In our paper (Jakobsson and Holloway 2008) a figure showing $\mathrm{MgO}$ versus weight $\%$ melt is printed twice and the $\mathrm{CaO}$ versus weight $\%$ melt figure is missing. Figures 5-9 are therefore reprinted here.

\section{References}

Jakobsson S, Holloway JR (2008) Mantle melting in equilibrium with an Iron-Wustite-Graphite buffered $\mathrm{COH}$-fluid. Contrib Mineral Petrol 155(2):247-256. doi:10.1007/s00410-007-0240-6

The online version of the original article can be found under doi:10.1007/s00410-007-0240-6.

\section{S. Jakobsson ( $\square)$}

Institute of Earth Sciences, University of Iceland,

Reykjavik, Iceland

e-mail: sigjak@raunvis.hi.is

\section{J. R. Holloway}

School of Earth and Space Exploration and Department

of Chemistry and Biochemistry, Arizona State University,

Tempe, USA

e-mail: John.Holloway@asu.edu 



Figs. 5-9 The figures show major element compositions, $\mathrm{SiO}_{2}$, $\mathrm{Al}_{2} \mathrm{O}_{3}, \mathrm{FeO}, \mathrm{MgO}$ and $\mathrm{CaO}$, of experimental melts as function of weight percentage melt as calculated using modal calculations. The

tie line in Fig. 6 suggests an increase in $\mathrm{Al}_{2} \mathrm{O}_{3}$ towards a maximum corresponding to garnet exhaustion in the residue 